\title{
Crooked Calf Syndrome: Managing Lupines on Rangelands of the Channel Scablands of East-Central Washington State
}

\section{By Kip E. Panter, Ernie Motteram, Daniel Cook, Stephen T. Lee, Michael H. Ralphs, Tom E. Platt, and Clive C. Gay}

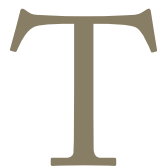

he Channel Scablands of east-central Washington was created by enormous cataclysmic floods toward the end of the last ice age about 12,00015,000 years ago. ${ }^{1}$ Before that time, large glacial masses pushed south, filling the Okanogan Valley of Washington, the Flathead and Swan Valleys of Montana, and the Purcell Valley of Idaho. As the glaciers expanded southward across northern Idaho into Montana, ice dams blocked the Clark Fork River drainage, creating the ancient glacial Lake Missoula. It is reported that the ice damns filling those valleys were over 30 miles wide. Lake Missoula had no outlet, and the water rose until it finally floated the ice dam, suddenly breaking loose, releasing huge torrents of water in a very short time (three-to-five days). These massive releases of water (which occurred multiple times) scoured the rich Palouse silt from the landscape, cutting deep into the basalt bedrock on its rapid descent across east-central Washington down the Columbia River basin to the Pacific Ocean (Fig. 1). Repeated flooding left massive areas of rocky, gravely moonscapes, exposed bedrock, dry creek beds, and "coulees." Outcroppings or large mounds of rich farm land supporting crops of wheat and lentils are interspersed within the flood-stripped scablands, a reminder of the rich soil that once covered this region.

Lupines flourish in the rugged scabland region of east-central Washington (Fig. 2). Deep-rooted leguminous lupines take advantage of scant soil moisture and remain green late into the grazing season, when they become a preferred feed for grazing cattle. Several lupine species have been identified on range pastures in Washington State: Lupinus sericeus (silky or bitter lupine), Lupinus leucophyllus (velvet or sweet lupine), and Lupinus sulphureus are common on scabland pastures. The lupine L. leucophyllus contains the alkaloid anagyrine. When pregnant cows graze anagyrinecontaining lupines during the last half of the first trimester and early part of the second trimester of gestation they are susceptible to "crooked calf syndrome" (40-100 days gestation). Although toxic alkaloids are believed to be a deterrent to cattle grazing lupines, the presence of senescent grasses and dormancy of once desirable forbs provide few options late into the grazing season, and hunger apparently overrides deterrent factors. As a result, cattle resort to grazing lupines, including L. leucophyllus, a species that causes birth defects (teratogenic). In addition to being toxic, this species is rich in nutrients $(8-10 \%$ protein in vegetative portions and over $15 \%$ protein in seed pods).

The incidence of crooked calf syndrome on ranches utilizing the Cow Creek drainage of the Channel Scablands, an area covering approximately 800 square miles, is $1-5 \%$ annually. ${ }^{2}$ Most ranchers have come to accept this degree of risk as part of running cow-calf operations in this region. However, when the incidence exceeds $5 \%$, as it has on a cyclic basis during the last 50 years or more, losses are unacceptable and can be catastrophic. Since 1980 eight years have been recorded in which one or more ranchers on the scablands have reported high incidence of lupine-induced crooked calf syndrome. The losses attributed to crooked calf disease represent a severe constraint to management and threaten the economic viability of ranches and local communities.

In 1997 ranches in this area sustained the loss of 40-65\% of their calf crop. The details of these episodes of crooked calf disease are provided by Lee et al. ${ }^{3}$ The occurrence of crooked calves can be represented using a bell-shaped 


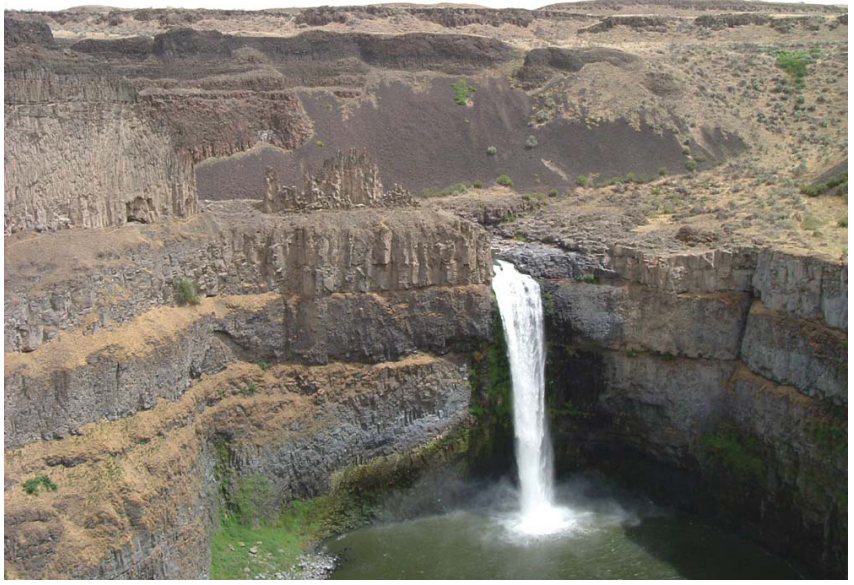

Figure 1. Palouse River Falls and coulee in east-central Washington showing the landscape and a remnant of the glacial Lake Missoula floods that created the Channel Scablands.

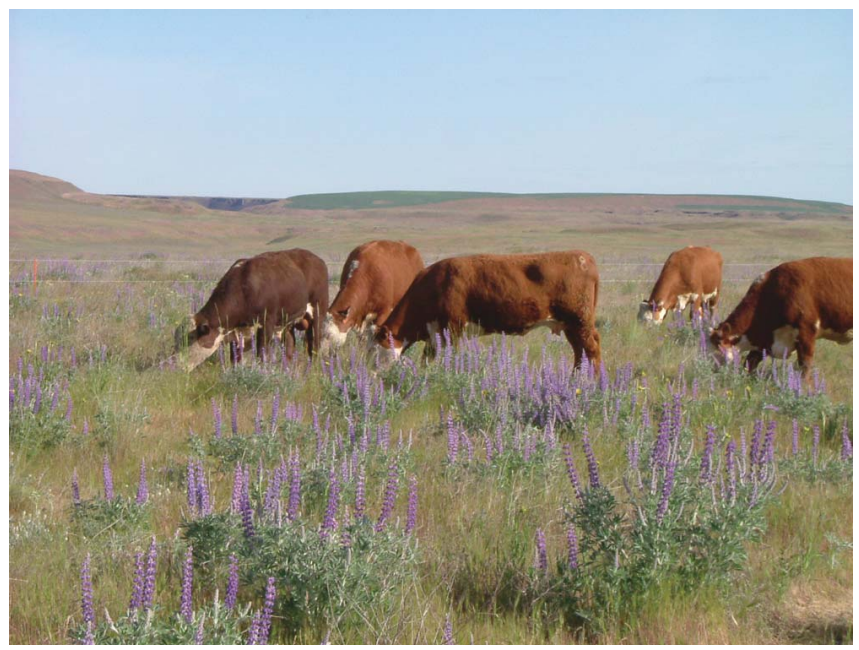

Figure 2. Research cattle grazing on a typical pasture infested with $L$. leucophyllus in the Channel Scablands region.

distribution pattern beginning in mid-January and tapering off in early to mid-May with the majority of the crooked calves born in February and March (Fig. 3). This distribution pattern is in concurrence with early May to July breeding employed by these ranches. This schedule exposes cows to lupine during susceptible stages of gestation. The problem is complex because stocking rates, lupine availability, cow age, lupine alkaloid concentrations, and lupine growth stage were all evaluated, yet no single factor emerged as the dominant causative factor in our analyses.

\section{Risk Factors}

Ranchers can often avoid the disease by calving in the fall rather than the spring. With fall calving, cattle graze the range at a period of pregnancy when the fetus is not susceptible to the effects of the lupine's alkaloids, but this requires

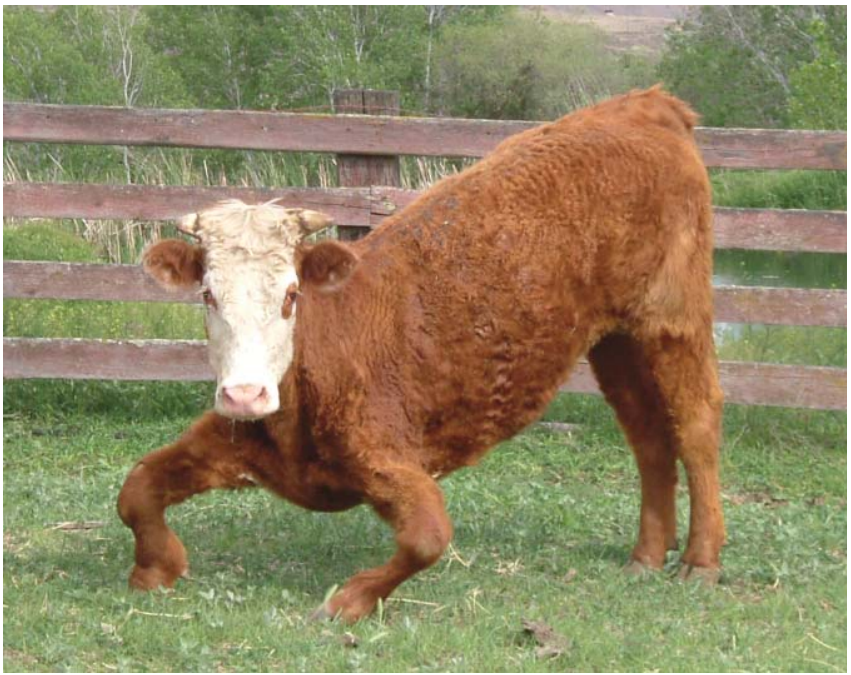

Figure 3. Yearling crooked calf salvaged for home use. Note: as the steer continues to grow, the front legs will break down.

grazing at times of suboptimal forage quality. There is a significant economic penalty. It requires a major outlay for winter feed and generally requires the ranch to have hay land. Rangeland forage is not used as efficiently because animal demand is not synchronized with forage supply.

Because of the ubiquity of L. leucophyllus on ranches in this region, all cows that are bred to calve in the spring are exposed to teratogenic alkaloids during fetal susceptibility and are therefore at risk of calves developing crooked calf syndrome. Despite this, in the same management group, only a proportion of cows will give birth to crooked calves, despite the fact that all cows in the herd had similar exposure to toxic lupines during critical periods of pregnancy (Figs. 4 and 5). This difference in birth outcome could be

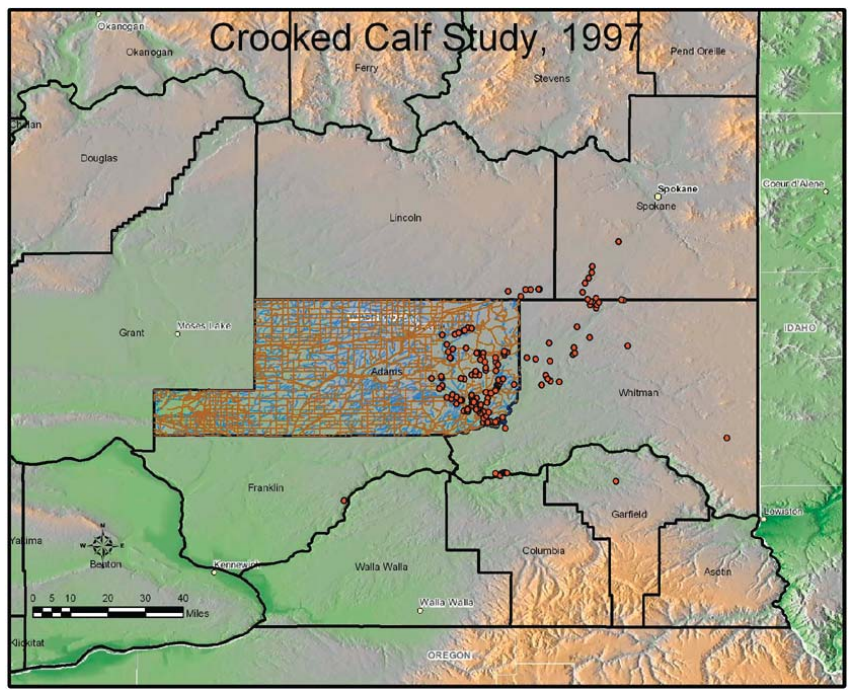

Figure 4. Map of the study area showing point locations of lupine plants collected in east-central Washington for identification and chromatography during 1997 in areas of known crooked calves. 


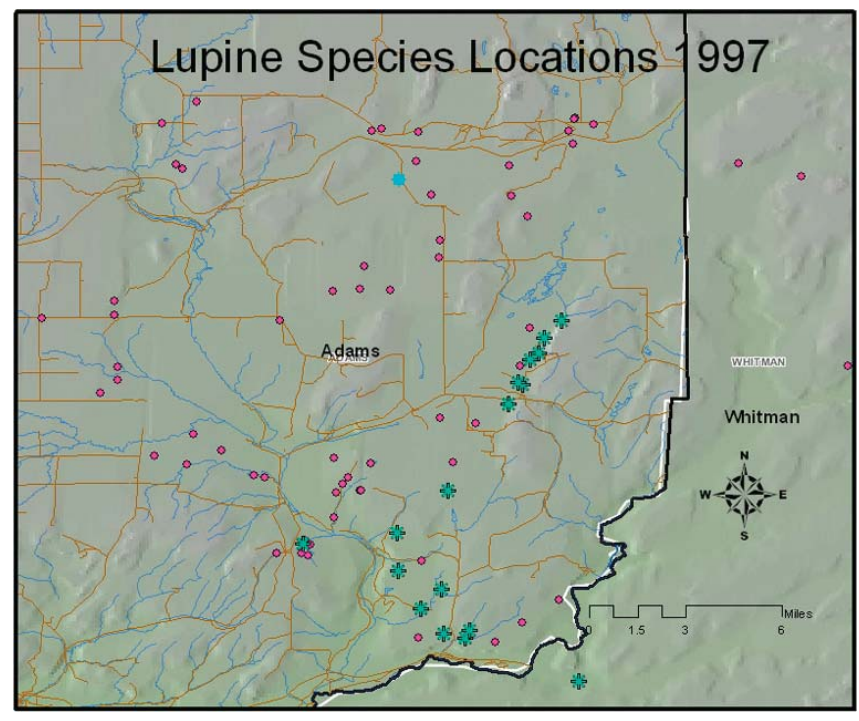

Figure 5. Expanded map of the Adams County region of the scablands. Note: the small pink dots denote $L$. leucophyllus (the lupine that causes crooked calves), and the blue/green stars denote $L$. sericeus (the lupine that poses no risk). Crooked calves have occurred in every location where $L$. leucophyllus is located. The single bright blue dot denotes a point where the plant was taxonomically called $L$. sericeus, but the chemical profile was the same as L. leucophyllus, and crooked calves occurred in this area. This is significant because it supports the notion that taxonomy, although important, does not provide enough information and can, in fact, mislead the decision-making process. Therefore, chemical analysis is critical in determining risk of lupine-induced crooked calf syndrome.

the result of a difference between the dams in the adaptive response to anagyrine, or in its metabolism with repeated exposure to anagyrine, or it could be a reflection of individual cow grazing preferences and/or aversions to lupine.

\section{Chemistry}

Alkaloids in the lupine family are of two classes, quinolizidine and piperidine, both of which contain toxic and teratogenic (causes birth defects) compounds. Over 150 quinolizidine alkaloids have been identified in various leguminous genera, including Lupinus, Laburnum, Thermopsis, Sophora, and Cytisus species. Although all of these alkaloids are considered toxic, structural differences elicit a wide variation in clinical effects. This variability is generally thought to occur because alkaloids differ in how tightly they bind to receptor sites in cells, and this binding affinity largely determines the potency of the alkaloid to interfere with normal cell function and subsequently cause birth defects. Thus far, four lupine alkaloids, one quinolizidine (anagyrine) and three piperidine (ammodendrine, N-methyl ammodendrine, and $\mathrm{N}$-acetyl hystrine), have been shown to cause birth defects. The most significant alkaloid involved in crooked calf syndrome appears to be anagyrine. Anagyrine is widely distributed in most lupines and was identified as the specific teratogen (compound causing birth defects) in the mid-1970s by Poisonous Plant Research Laboratory chemist Dr Richard Keeler. The identification of anagyrine as the probable teratogen followed intense scientific investigations in the northwestern United States during the late 1960s and early 1970s that ultimately linked large outbreaks of crooked calf syndrome to lupine. Although the piperidine alkaloids have been shown to be more toxic and apparently more teratogenic, their distribution is limited to fewer lupine species, and to date none of these species has been implicated in field cases of crooked calf syndrome. However, the potential risk is obvious, especially if certain environmental or management circumstances occur. This was evident in a recent field case in central Idaho where Lupinus argenteus, containing only ammodendrine and $\mathrm{N}$-methyl ammodendrine, was responsible for cattle deaths, but not birth defects. Overgrazing and failure to move cattle to fresh pastures forced cattle to graze lupine almost exclusively, resulting in poisoning and death.

Alkaloid concentration and chemical profiles vary widely between and within lupine species. Season, year, environment, location, and plant phenology may all influence alkaloid concentrations. However, recent research suggests that the alkaloid profile is relatively consistent over time and can be used as an identifying taxonomic feature (D. Cook, unpublished data, 2008) to differentiate lupine species. Research has focused on three lupine species on the scablands; however, only one contains the toxin anagyrine ( $L$. leucophyllus), and this is the only species that poses a significant risk to grazing cattle. L. sulphureus contains the teratogen ammodendrine, but this species is isolated to only a few pastures; it matures very early in the growing season, and alkaloid levels typically have declined to a low level before pregnant cows have access to the plants. The third lupine species, L. sericeus, does not contain anagyrine in the Cow Creek drainage, is not very palatable, and poses no risk for crooked calf syndrome.

\section{Why Do These Deformities Occur?}

In 1983 we speculated that the skeletal birth defects known as crooked calf syndrome were caused by an alkaloidinduced reduction in fetal movement during the susceptible stage of pregnancy. Since that time, and using ultrasound imaging in a pregnant goat model, we have confirmed this fact and determined that the deformities, including cleft palate, are a result of reduced or lack of fetal movement. This has been demonstrated in different animal species (sheep, cattle, goats, and pigs) and using other teratogenic alkaloids (hemlock, tobaccos) with the same mechanism of action and the same results. ${ }^{4}$

More detailed research efforts suggest that these alkaloids cross the placental barrier and inhibit fetal activity by blocking neuromuscular receptors, essentially "paralyzing" or "anesthetizing" the fetus. This lack of fetal movement is responsible for the cleft palate by stopping fetal head and 
neck movement on about the 40th day of gestation in cows and day 35 in sheep and goats. Failure of essential head and neck movement at this time prevents the tongue from dropping out of the roof of the mouth, and thus the tongue becomes a physical obstruction for normal palate closure. Similarly, when fetal movement is inhibited during specific stages of gestation, the lack of tendon, ligament, and muscle stretching that occurs with normal fetal activity results in the wide range of contracture defects that may occur at all articulating surfaces (joints) in the skeletal system.

\section{Grazing Studies}

Several intensive grazing studies have been conducted on the scablands to determine when and why cattle graze lupines. From 2001 to 2003, 8-11 cows grazed a 100-ha pasture with abundant forage to learn the composition of their diets. Each year cattle started grazing lupine around the first of July and continued eating it into August. The timing of lupine consumption was similar all three years and depended on the relative availability and maturity of associated forages. Cattle selected annual grasses (cheatgrass and medusahead) while they were still green during the first portion of the growing season. Crude protein concentration of cheatgrass was $8.5 \%$ of the dry matter weight at the beginning of the season, but declined to $5 \%$ at maturity (Fig. 6). As the annual grasses matured and died, cattle
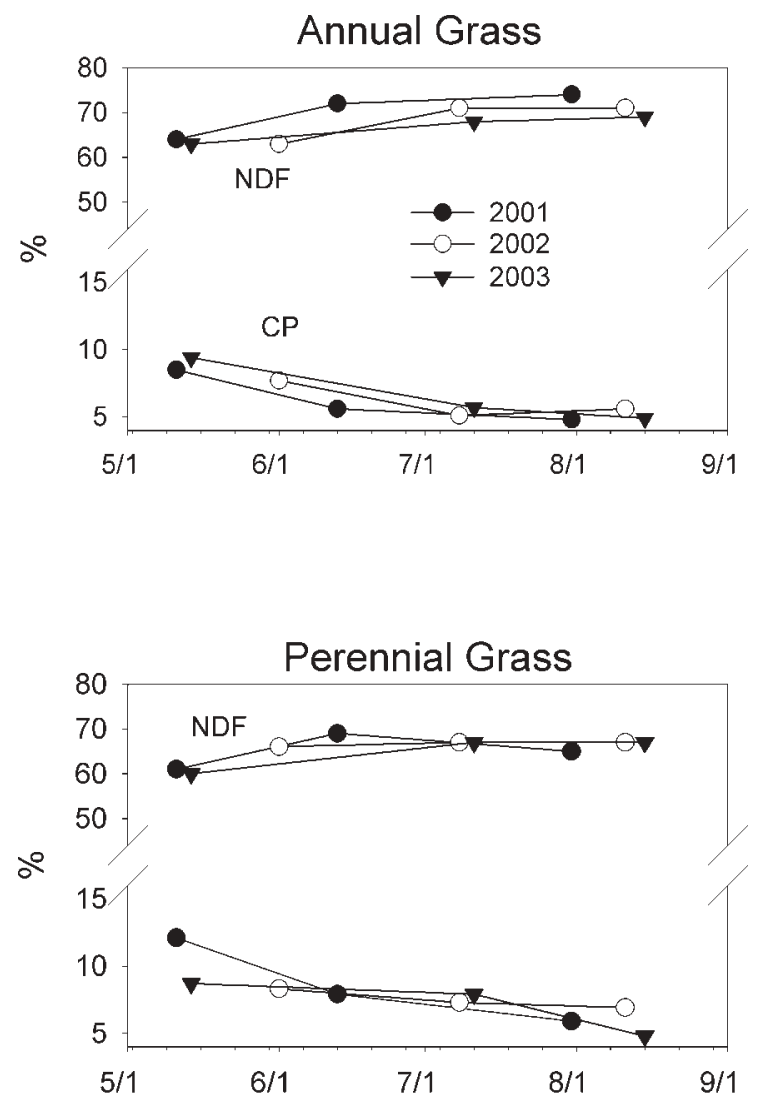

Figure 6. Nutrients by forage class. selected green forbs, such as fiddleneck, rush skeleton weed, and tansy mustard during mid-summer. Crude protein of forbs ranged from $10 \%$ to $14 \%$ during the first half of the season, and neutral detergent fiber (NDF) content averaged $55 \%$, compared to $65-70 \%$ in annual grasses. As these forbs were depleted, senesced, or died, cattle began selecting the deep-rooted lupine, which remained green and succulent longer than the other forbs. Crude protein content of lupine was $15 \%$ through the middle part of the season, and NDF remained below 55\%. Although it was the most nutritious forage throughout the season, cattle did not graze lupine until the other forages were depleted or matured. We suspect that its dense pubescence and/or its high alkaloid content early in its phenological development contributed to its lack of palatability. Using the same area, Lopez-Ortiz ${ }^{5}$ also reported cattle selected velvet lupine only after annual grasses and other forbs became limited. However, intensive rotational grazing systems can force cattle to graze lupine earlier in the growing season (M. H. Ralphs and J. Pfister, unpublished data, 2007-2008). Grazing systems that concentrate large numbers of animals in relatively small areas for short periods deplete desirable forages and force cattle to graze the relatively unpalatable lupine.

There is a toxic window (Fig. 7) comprised of the critical period of gestation when the fetus is susceptible to the toxic effects of anagyrine in lupine. The general breeding season
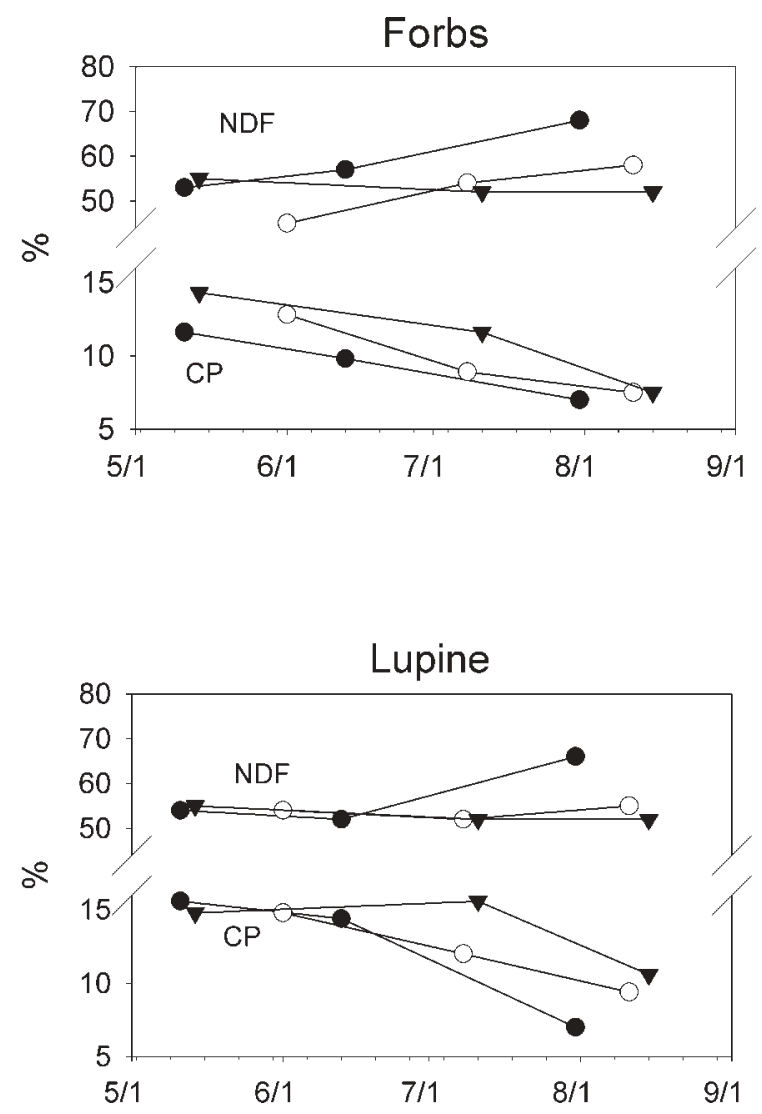
Anagyrine in plants and Lupine in diets

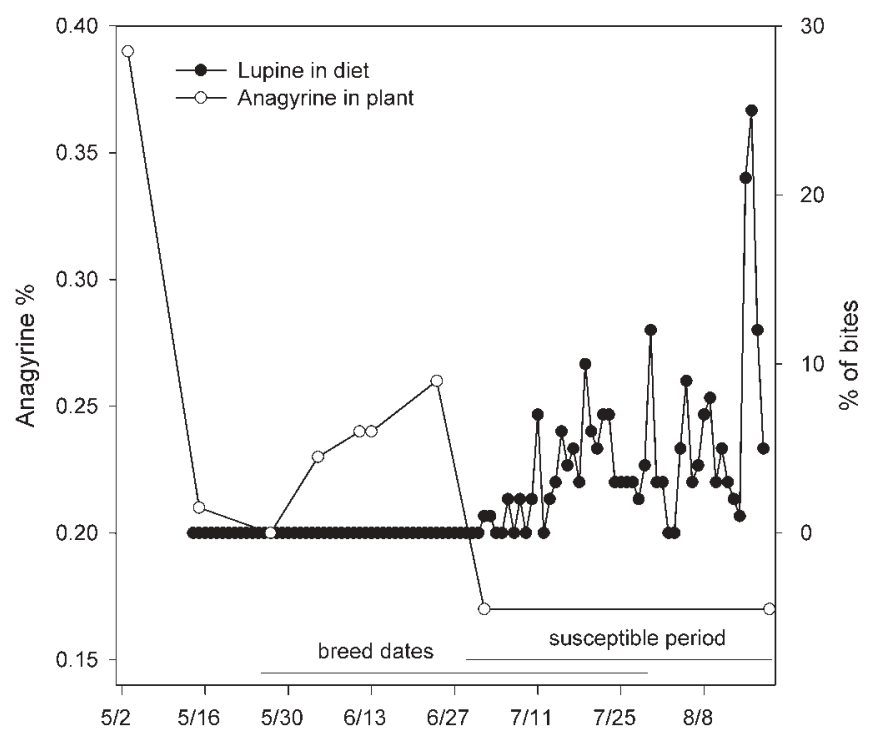

Figure 7. The toxic window for lupine, showing the overlap between the susceptible period of gestation when cows grazed lupines and high anagyrine content in the plants.

in this region is 1 May through 30 June. Therefore, the susceptible period of gestation (day 40-100) runs from 10 June to 8 October. Because study animals consumed lupine during July and August, ingestion of the teratogenic alkaloid anagyrine occurred during the critical portion of gestation. Anagyrine concentration was greatest in flowers and pods, which appear from mid-May through early July, but declined sharply following seed shatter in mid-July. Therefore, the overlap between the susceptible period of gestation, the time the cows were eating lupine, and the high concentration in the plant occurred during July.

The abundance of lupine is another factor influencing catastrophic losses. The winter of 1995 and spring of 1996 were wet (140\% of normal precipitation), which apparently contributed to a large increase in lupine population numbers responsible for the catastrophic losses in 1997. Although most forage species should be more abundant during wet years, grazing of lupine is apparently influenced by quality (dry and mature) of other forages rather than quantity. We have estimated population size of velvet lupine ( $L$. leucophyllus) from 2001 to the present, and its numbers have declined linearly across years. This corresponds to the relatively infrequent cases of crooked calves during this period.

\section{Management}

Reducing losses from lupine-induced crooked calf syndrome requires multiple approaches to be successful. However, a simple rule may be applied: avoid grazing toxic lupines by pregnant cows during the susceptible stages of gestation (day 40-100) on pastures where lupines containing anagyrine are present. Having said this, these ranges can be utilized optimally by following a few management practices:

1) Identify potential poisonous plant threats in pastures and determine what specific lupine species are present.

2) Determine the chemical makeup of the lupine species. Although taxonomy is important in classifying and identifying lupine species, it has little relevance in predicting relative risk to livestock producers. Chemical characterization and identification of alkaloid profiles is required to determine relative risk of toxicity and livestock losses. If anagyrine or one of the piperidine alkaloids is present in a lupine sample submitted for identification, then the potential risk of calves being affected by crooked calf syndrome can be estimated. Once the concentrations of offending alkaloids are determined, then the historical incidence of crooked calf syndrome, lupine density, forage conditions, and breeding schedules are evaluated for potential risk.

3) Adjust breeding schedules to avoid exposing pregnant cows to lupines when they are at highest risk (40-100 days gestation). Where high incidence of crooked calf syndrome occurred in multiple years, fall calving schedules have virtually eliminated crooked calf incidence. This must be carefully reviewed to ensure this is the best approach.

4) Restrict access to lupine in July when cattle begin eating lupine and anagyrine levels are elevated. Also restrict access of bred cows to pastures with lupine during years when toxic lupines are abundant.

5) Use intermittent grazing. Although this approach is more management intensive, it has the potential to reduce losses and increase pasture utilization. Crooked calves are not produced when pregnant cows graze toxic lupine in a single episode, or even in a few repeated episodes, but rather a relatively extended period of sustained ingestion during a seven-to-ten-day period. An understanding that the fetus must be exposed to the alkaloids over a prolonged period clarifies the intent of the intermittent approach to break the cycle of grazing, thus allowing the fetus to regain activity and restore movement and thereby reduce the likelihood of twisted joints. Research to verify this approach is ongoing.

6) Furthermore, closely observe cattle to identify so-called lupine eaters and remove them once lupine ingestion is observed. This can remove those cows most likely to have crooked calves. Additionally, lupine eaters may teach their calves and other cows to eat it, a condition referred to as social facilitation or "peer pressure."

7) Drought conditions in the scablands region since 1997 have reduced lupine populations significantly and diminished the incidence of crooked calf syndrome. However, lupine seed reserves in soils ensures future 
outbreaks when environmental conditions are favorable. Knowledge gained by research can be modeled over a range of scenarios and allow us to predict probable outbreaks of crooked calf syndrome and avoid catastrophic losses.

8) Use stockers, open heifers, or other livestock species to harvest forages on pastures with lupine. Lupine is nutritious forage, particularly on dormant scabland rangelands dominated by annual grasses. Some ranchers have utilized this in their management strategies and avoid using pregnant cows on high-risk pastures. Instead they utilize the good forage value of lupines with stockers and open replacement heifers.

9) Use herbicide control. Some smaller ranches have achieved lupine control with herbicides, and most ranchers use some amount of herbicide to reduce risks. However, the pastures are very large, the lupines are widely distributed over the range, and the terrain is very difficult. Lupine seed has a hard coat and remains viable in the soil for many years. Most scabland ranchers consider herbicide application ecologically unsound because herbicides are nonselective and many valuable range forage plants are also destroyed. The Channel Scablands are not suitable for agricultural pursuits other than grazing.

\section{Conclusions}

Since the large calf losses during the 1996-1997 calving season the incidence of crooked calves in the scablands has returned to pre-1996 levels. However, some ranches have continued to experience up to $5 \%$ incidence, with several of the 1997 ranches reporting losses of about $12 \%$ in 2008. Two ranches on the Snake River Breaks reported unusually high numbers of crooked calves in the spring of 2008. Even though lupine populations appear to have steadily declined overall, there are apparently isolated pockets of lupines in certain pastures. Since 1997 our monitoring of lupine populations has documented an overall decline in lupine population size, a trend that is believed to be associated with co-occurring drought conditions. However, the isolated populations of lupine where crooked calves continue to occur may be the result of smaller scale climatic events that has allowed populations to persist at pre-drought levels. Seed reserves are believed to be poised to take advantage of re-emerging favorable environmental conditions and reinforce the cyclic boom-bust population dynamics of lupine, with each cycle causing catastrophic losses affecting cow calf operations. Integrated research efforts during the last eight years are improving our understanding of conditions leading to these losses. Further discovery and synthesis of existing data are planned that will enhance our ability to develop proven management options that effectively reduce both persistent and catastrophic losses experienced by livestock producers.

\section{References}

1. Alt, D. 2001. Glacial Lake Missoula and its humongous floods. Missoula, MT, USA: Mountain Press Publishing Company. $199 \mathrm{p}$.

2. Gay, C. C., K. E. Panter, E. Motteram, J. M. Gay, H. Hantz, T. Wierenga, and T. Platt. 2007. Risk factors for lupine-induced crooked calf disorder in east-central Washington State. In: K. E. Panter, T. L. Wierenga, and J. A. Pfister [EDs.]. Poisonous plants: global research and solutions. Cambridge, MA, USA: CABI. p. 156-164.

3. Lee, S. T., K. E. Panter, C. C. Gay, J. A. Pfister, M. H. Ralphs, D. R. Gardner, B. L. Stegelmeier, E. S. Motteram, D. Cook, K. D. Welch, B. T. Green, and T. Z. DAvis. 2008. Lupine-induced crooked calf disease: the last 20 years. Rangelands 30(6):13-18.

4. Panter, K. E., L. F. James, and D. R. Gardner. 1999. Lupines, poison-hemlock and Nicotiana spp: toxicity and teratogenicity in livestock. Journal of Natural Toxins 8(1): 117-134.

5. Ortiz, S. L., J. A. Pfister, K. L. Launchbaugh, and C. C. GAY. 2007. Forage availability and body condition affect intake of lupine (Lupinus leucophyllus) by grazing cattle. Professional Animal Scientist 23(5):459-466.

Authors are Reproductive Toxicologist and Research Leader, kip.panter@ars.usda.gov (Panter), Plant Physiologist (Cook), Research Chemist (Lee), and Rangeland Scientist (Ralphs), Poisonous Plant Research Laboratory, Agricultural Research Service, United States Dept of Agriculture, 1150 E 1400 N, Logan, UT 84341, USA; Instructional Supervisor (Motteram) and Professor Emeritus (Gay), Field Disease Investigation Unit, College of Veterinary Medicine, Washington State University, Pullman, WA 99164, USA; and Area Extension Educator, Washington State University Extension, Lincoln County, Davenport, WA 99122, USA (Platt). Published with the approval of the Director as Journal Paper No. 8041 of the Utah Agricultural Experiment Station. A full citation section can be found at http://www.srmjournals.org. 